\title{
From Discussion to Fist-fighting: Was Strategic Maneuvering Derailed during the Debate on the Presidential Age Limit Bill in Uganda?
}

\author{
Edith R Natukunda-Togboa ${ }^{1}$ \\ ${ }^{1}$ Head, Department of European and Oriental Languages, Makerere University, Uganda \\ Correspondence: Edith R Natukunda-Togboa, Head, Department of European and Oriental Languages, Makerere \\ University, Uganda. E-mail: enatukunda@gmail.com
}

Received: January 15, 2019

Accepted: February 15, $2019 \quad$ Online Published: April 23, 2019

doi:10.5430/elr.v8n2p1

URL: https://doi.org/10.5430/elr.v8n2p1

\begin{abstract}
Of recent, due its impact on political events and socio-political processes like general elections and peace building, parliamentary discourse has become the object of research in Africa. In Uganda, in particular, at different times in the country's history, it has been at the heart of fomenting conflict, but also key in fostering peace. It is of historic importance that we analyse how the controlled institutionalized parliamentary discourse during the presidential age limit debates degenerated to fist fighting and chair hurling in the Uganda Parliament. Using the pragma-dialectical, the rhetorical and linguistic approaches this study seeks to check the arguer's commitment to pursuing a reasonable argumentation as s/he tries to discursively resolve the difference of opinion which is usually at the heart of parliamentary debates. Through a review of the atmosphere surrounding the presidential age limit debate and the two critical sessions of the relevant parliamentary discussions, the author tries to establish whether this discursive resolving of differences of opinion was achieved or whether there are factors that contributed to derailing the discursive strategic maneuvering.
\end{abstract}

Keywords: strategic maneuvering, the pragma dialectic, rhetoric and linguistic approaches, parliamentary discourse

\section{Introduction and Background}

In spite of the growing popularity of viewing and airing parliamentary proceedings, scholarly interest in the study of parliamentary discourse in countries like Uganda has been low. Yet of recent, due its impact on political events and socio-political processes like general elections and peace building, parliamentary discourse has become the object of research in Africa. In Uganda, in particular, at different times in the past, parliamentary discourse has been key in fostering peace, but it has also been at the heart of fomenting conflict. Relatedly, one notes that the parliamentary discourse that was used at the time of the Presidential Age Limit Debate in Uganda was "relative to social, political, and cultural formations ...reflecting and shaping ...social order...and shaping the individual's interaction with society"(Jaworski \& Coupland. 1999).

President Yoweri Museveni came to power in Uganda in 1986 at the head of a rebel army of the National Resistance Movement. In 2005, he had the constitution amended to remove term limits, enabling him to stand successfully for the third (2005), fourth (2011) and fifth (2016) consecutive terms. Under the Uganda Constitution of 1995, Article 102(b) with its 2005 and 2011 Amendments, a person standing for presidency had to be under 75 years of age which would make Museveni, now 75, ineligible to stand in the next polls in 2021. The parliamentary debate seeking to amend Article 102(b) of the Constitution was the first step towards scrapping the presidential age limit, which would allow the long-time leader Yoweri Museveni to continue staying in power. In Uganda's current context, the Bill lifting the age limit for presidential candidates was drawing the line between the struggle for citizen-responsive democratic leadership and the further weakening of the country's Constitution while creating grounds for a potential life presidency. In the past, in 1966, the first Constitution of independent Uganda had been abrogated and another one, which came to be known as 'the pigeon-hole constitution' was approved to replace it even before the MPs had debated it. The Age Limit Debate thus had, in the context of Uganda, turbulent undertones of the collective memory of yet another 'constitutional coup' (Mukasa, 2019).

From a pragma-linguistic perspective, we note that the parliamentary discourse that formed the base of the Presidential Age Limit debate belongs to the genre of political discourse. It was a discourse with an institutional framework of the Rules of Procedure of the Parliament of Uganda of 2006. As such, it displayed particular 
institutionalised discursive features and ritualised interaction strategies, while complying with a certain number of specific rules and constraints. Traditonally, the discursive interaction of parliamentarians is constantly marked by their institutional role-based commitments, by the dialogically shaped institutional confrontation and by the awareness of acting in front and on behalf of a multi-level audience. It is a discourse that is "negotiating the terms of candidature with its own purposes of "position claiming, persuading, negotiating, agenda-setting and opinion building"(Ilie.2006). Tangent to these purposes is the function of the Member of Parliament (MP) of contributing to the task of problem solving in connection with legal, and political deliberations and decision-making. During the time of the presidential age limit debate, the MPs were thus faced with the responsibility of Parliamentary discourse which is highly competitive, in that it seeks to position one side, the arguer's side, against the other, as they question each other's statements, their logical reasoning and credibility while eliciting emotional support for their own political stand-point. This limitation of space and time adds another layer of competition for MPs when they are playing their role in parliamentary discourse. As a linguist, I am not only taking into account the grammatical and semantic parameters of the parliamentary debate but I am also considering some extra-discursive parameters, in purpose of describing and analysing the parliamentary speeches as a "form of talk" by identifying and assessing its specific structural features and strategies (Goffman 1981).

\section{Theoretical Framework}

In terms of the theoretical framework to this study, I shall be using the pragma-dialectical theory to interrogate the strategies and output of argumentative discourse. This means that I will be checking the arguer's commitment to pursuing a reasonable argumentation as s/he seeks to tactfully resolve the difference of opinion by merits; which is usually at the heart of parliamentary debates. Advancing this line of thought, Van Eeemeren and Garssen observe that the pragma-dialectical theory demonstrates how "[keeping] the balance between maintaining reasonableness and aiming for effectiveness in every argumentative move requires continual strategic maneuvering on the part of arguers" (Eemeren \& Garssen. 2013, p.2). In making argumentative moves, arguers are not just striving to be reasonable in resolving the difference of opinion, but they are also, primarily trying to "be effective in resolving a difference of opinion in favour of their position by convincing the audience of the acceptability of their standpoint" "(Eemeren \& Garssen. 2013,p.2) According to the same source, the tension involved in pursuing the above two aims simultaneously " must be controlled to remain within the boundaries of reasonableness as defined by the rules for critical discussion" (cited in Eemeren \& Garssenp.2). Van Eemeren's model of a "critical discussion" is "dialectical because it involves rules that are instrumental in resolving the contestation and it is pragmatic because the argumentative moves are defined as speech or visual acts that are contributing to the various stages of the resolution process"(Eemeren.2017). Subsequently, the resolution process is defined as having several procedural points beginning with the confrontation stage in which the differences of opinion are explicitly stated, then follows the opening stage where the arguer performs several analytic transformations and finally the concluding stage where the arguer hopes to close favourably the critical discussion. In order to demonstrate the conceptual design of parliamentary discourse, we could use a graphic format, by adjusting what Eemeren proposes for an argumentative discourse (2017).

\section{A Graphic Format of the Parliamentary Discourse}




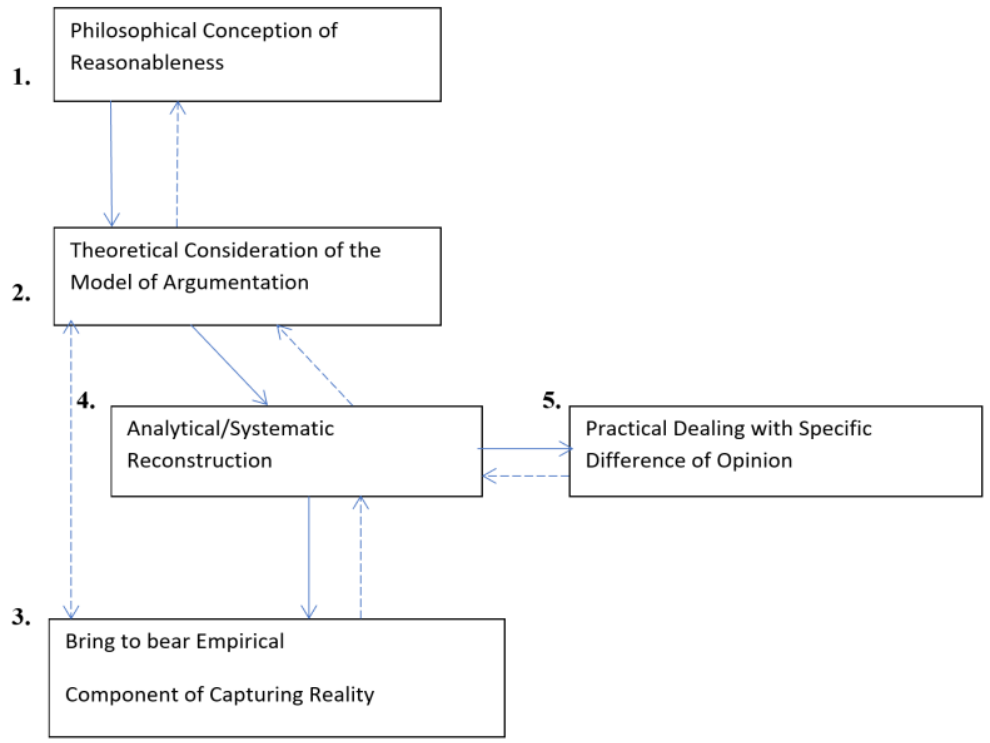

An adapted and modified conceptualization inspired by Eemeren F.H. van Informal Logic, Vol. 37 N0.4 (2017) p. 324.

The conceptualization of any argumentative discourse, which includes parliamentary debate, as described by Frans van Eemeren, encompasses the categorization of "stand points, differences of opinion, starting points, argument schemes and argumentation structures" that underlie the systematic reconstruction of the critical discussion (Eemeren.2017). In each argumentative practice, as is the case of parliamentary debate, the arguer will begin with explicitly or implicitly scrutinizing the merits or demerits of the communicative activity type basing on the institutional rules of procedure. S/he will consider the strategic concessions that may have to be made in order to submit the empirical evidence interpreted in a manner that will favour his/her political leanings. If the pragmatic argumentation has been used, the critically pertinent question will be posed accordingly to motivate a possible solution to the critical discussion (Eemeren. 2017.337).

In addition to the pragma-dialectical theory, this article also employs some features of the rhetorical model of argumentation that add value to the various stages of "strategic maneuvering". Basing on the work of Christopher Tindale (2006), the author contends that there are three important "dimensions" to argumentative discourse that should be added as a supplement to the theoretical framework of the present article. The first one involves "the selection of topics.... and the material available" to bring out their topical potential at each stage of the discussion. The second dimension involves adapting oneself to audience demands; this amounts to creating empathy for your argumentation (van Eemeren \& Houtlosser 2000b. 298). The third dimension involves exploiting the presentational devices used strategically at each stage. These may be rhetorical figures or metaphors or even ploys that will be used to impress upon the minds of the members of the audience and to "create presence" (Tindale. 2006). Rhetoric argumentation lays its focus on the audience's perspective, acting on the listener and [hoping] to modify what appears to be the case. That is why in this approach, "the arguer's commitment to proceeding reasonably may be overruled by the aim of persuasion" (Tindale.2006) and when this happens, strategic maneuvering has been "derailed" and hence a fallacy has been committed. Eemeren, Garssen \& Meuffels also underscore the danger of derailing strategic maneuvering as they point out that "any move that is a threat to the resolution process at any stage can be considered as a fallacious manoeuvre (van Eemeren, Garssen \& Meuffels.2009). Once this happens, critical reasonableness that encourages the systematic submission of the protagonist's standpoint to the critical doubts of the antagonist will be jeopardised and the interchange of arguments that is expected to result in a resolution of the difference of opinion by both parties will be sabotaged (Gabor.2014). The occurrence of fallacies in the case of the presidential age limit debate in Uganda, as we shall later demonstrate, had disastrous effects on the process of the resolution of differences of opinion.

The theoretical framework to this article finally adds some components of linguistic perspectives to discourse analysis given that the study is being conducted within the realm of a political discourse. Politics, as Fairclough the critical discourse analyst has observed, "is struggle for power in order to put certain political, economic and social ideas into practice. In this process, language plays a crucial role, because every political action is prepared, accompanied, influenced and played through language " (Fairclough. 1995 cited by Mwiinga. 2015). As a political 
communicative activity type, parliamentary discourse is typically "strongly formalized and its institutional conventions are fully explicit with... regulative rules".(Eemeren, Bart a\& Garssen, 2011.2) As part of the political communicative domain, parliamentary discourse has its institutional points which manifest themselves as speech events that are prototypically part of the procedural 'starting points' of the critical discussion ". (Eemeren, Bart \& Garssen, 2011.2). In this line of thought therefore, the author will analyse the way in which the different stages of the argumentation characterise and project the outcome of the communication activity.

Indeed as Cornelia Ilie has observed, the rules controlling parliamentary discourse are subject to a complex interplay of socio-cultural and institutionalized constraints so much so that constitutive linguistic politeness and confrontational structures are discourse integrated (Ilie. 2006). For instance, the turn-taking sequencing of parliamentary interactions that show linguistic constraints was paralleled by institutional constraints imposed on the orator in the chambers. In the case of the parliamentary debate of the presidential age limit in Uganda, the study will show how collective undertakings supposed to lead to converging and complementary discursive contributions were manipulated into adversarial attacks that were institutionally orchestrated and jointly performed by both the protagonists' and antagonists' sides. Face-threatening acts marked by 'unparliamentarly' language and behaviour grew from mitigated reproaches to confrontational accusations and chaotic trading of insults. It is of historic importance that we analyse how the controlled institutionalized parliamentary discourse degenerated to fist fighting and chair hurling in the presidential age limit debate.

\section{The Atmosphere Surrounding the Debate on the Presidential Age Limit in Uganda}

This section of the article endeavours to bring out the extra-linguistic parameters that impacted the parliamentary discourse since the chaotic events of $19^{\text {th to }} 26^{\text {th }}$ September 2017 were not recorded in the official Hansard that records proceedings of the Parliament of Uganda. However, all these took place around and within the parliamentary chambers and they set the tone for the two sessions of September $27^{\text {th }}$ and $28^{\text {th }}$ on the Presidential Age Limit Amendment.

On the $19^{\text {th }}$ September 2019, The Observer reported that "MPs expressed concern over the unusual heavy deployment of military and regular policemen...in the precincts of parliament." The Police responded by saying that "several youth groups have been planning to storm parliament over the removal of the age limit." The reader needs to be informed that the preceding week, the ruling National Resistance Movement(NRM) Caucus within the Parliament of Uganda had endorsed the lifting of the presidential age limit in order to have President Museveni seek another term of office after clocking 75 years. During that same week, a section of NRM MPs opposed to the amendment had called a press conference and stated that they would fight the age limit removal ..."by tearing the documents related to the Bill." They were immediately summoned by Police for "offensive communication and inciting violence." In connection to that press conference, the Minister for Investment and Privtisation, Ms. Evelyne Anite responded by saying that the ruling party "has the army on [its] side". (The Observer 19/09/2017).

On the $21^{\text {st }}$ September 2017, the much anticipated motion by MP Raphael Magyezi, of Igara West was not indicated on the Order Paper. Nonetheless the opponents to the motion came ready to block it and there was a palpable tension between them and the supporters of the motion outside the Parliament. When the Deputy Speaker of Parliament, Jacob Olanya opened the session, there was foot stumping, clapping and the repeated singing of the National anthem by the opponents to the "Age Limit Motion" mostly dressed in red with a red bandana. The supporters of the motion adorned different shapes and combinations of yellow were also heckling back. The Deputy Speaker indicated that there were 2 problems which were blocking the debates: "members of Parliament had refused to sit down [and] he [was] not ready to chair a parliament that does not want to sit" consequently he adjourned the parliament. (The Independent 21/09/2017).

When Parliament resumed on Tuesday $25^{\text {th }}$ September 2017, the Busongora North MP William Nzoghu, claimed that some members had entered the House with guns and "even the Speaker was not safe to debate in such an environment". Busiro South MP Merdard Lubega Sseggona asked the Speaker to adjourn the House for security reasons but Ms. Kadaga said she could "not adjourn the proceedings on mere allegations". MPs who purportedly were searching for the gun subsequently scuffled with those supporting the Bill until the situation went out hand, chairs started flying, some MPs fled to safety while others tried to calm those who were baying for blood. ${ }^{1}$ The

\footnotetext{
${ }^{1}$ Refer to
}

https://www.monitor.co.ug/News/National/Watch-live-Parliament-debate-age-limit/688334-4112780-146xffk/index.html Chaos in Parliament as MPs fight over age limit., and

https://www.reuters.com/article/us-uganda-politics/lawmakers-brawl-in-uganda-parliament-for-second-day-over-presidential-age-1 
following day $26^{\text {th }}$ September 2017, the Speaker suspended some 25 MPs over the chaos that had marred the week's age limit debate. They resisted the suspension and had to be forced out by security amidst fierce fighting. The Reuters journalist present in parliament attests that "he saw microphone stands being used as weapons, and at least 2 female lawmakers being carried out after collapsing. People exchanged kicks after security personnel were called to remove lawmakers "who had been ordered out of the chambers" (The Telegraph, 28/09/2017). Political opposition parties not represented in Parliament threatened to go to court so that court "can pronounce itself on whether what went on in the parliamentary chambers on that day was not illegal....MPs were mishandled by soldiers, lawful procedures were under-looked and the media was barred from broadcasting the events." (Asuman Basalirwa, President of Justice Forum Party). (New Vision 27/09/2017).

But most importantly, concerning the substantive issue on the floor, after the heated debate, in a calculated turn of events, the Speaker Kadaga ruled that the motion to debate the presidential age limit "had been allowed." Criticising this move, on October $3^{\text {rd }} 2017$, the academic staff, School of Law, Makerere University, issued a statement in a document titled "Rape of the Sanctity of Parliament."(The Observer 6/10/2017). Whatever the criticisms and protests were made and however loudly and forcefully the members of parliament tried to show that the difference of opinion had not been resolved, the motion had been allowed and the debates continued. The majority of the ruling party MPs were now the ones continuing the one-sided debate with no opposition. The two sessions of the Age Limit debate that follow therefore must be received with the perceived arrogance of the ruling majority, the frustration of banned media coverage and minimum respect for democratic parliamentary discussion. This context of complete denial of the space and time to discuss for one side of the parliament was set up even before the debate itself was set into motion, hence the importance of retracing the pre-debate atmosphere. The atmosphere of heavy surveillance, banning of demonstrations (The East African 18/10/17), security agents entering parliament and handling the opposing MPs manu militari, could only portend a derailed discourse. Under the threat of beatings, arrestation and suspension from parliament, there was no chance for conformity to any rules of procedure. Consequently, all the stages of the critical discussion had to collapse and that is why there is no Hansard record of the two days of fist-fighting and chair flinging during the presidential age limit debate in Uganda. The chaotic pre-debate atmosphere of violence built up into an extra-linguistic factor that heavily contributed to the derailment, or even worse, the distortion of the strategic maneuvering of parliamentary discourse at the time under study.

\section{Analysis of the Parliamentary Debate on the Presidential Age Limit in Uganda}

\subsection{First Session of the Debate}

Following the suspension of the 25 MPs and a minister for paralyzing parliament, and the walking out of most opposition members, on $27^{\text {th }}$ September 2017, the Hansard, the Official Report of the Proceedings of the $21^{\text {st }}$ Sitting of the Parliament of Uganda starts with its ritualized discourse of the Speaker commenting on the Report by the Chairperson Committee on Legal and Parliamentary Affairs:

"In the Chairperson's report, there were two matters that were originally part of the Bill; one is the issue of term limits. We would like to know under whose instructions that part was addressed. There was also the issue of adjusting the term of parliament."(Hansards, 20/12/2017)

The Chairperson of the above mentioned committee Hon. Jacob Oboth then goes on to state: "Madam Speaker, for the record of Parliament you have asked where we got what we reported on. There is nothing in that report that we did not get through a process of consultation".

Now if you consider the question posed and the answer that was given, you will notice that the two do not tally. The process of consultation does not alter the terms of reference of a parliamentary committee. But the implied intention was for the Speaker to introduce the extraneous matters done outside the terms of the Bill on the presidential age limit so that they could be included in the discussions and the motion that would ensue from there. The selection of the topics for the rhetoric, and the material there in, as noted by Tindale (2006) was being manipulated right on the floor of parliament and that caused immediate interruption.

The interruption sought to "inform" parliament on how the Rules of parliament procedure had been violated by discussing the Presidential Age Limit Bill presented as a private member's bill; this was tantamount to directly discussing a Constitutional amendment. The "information" was offered as a ploy to embarrass the Speaker. As an experienced debater herself, she identified the discursive pitfall. She therefore "noted" the "information" but no action was taken. Instead the Speaker directed: "Hon. Member please take your seat. We asked the Chairperson to

imit-idUSKCN1C21VI Lawmakers brawl in Uganda Parliament for second day over presidential age limit. 
explain the proposals." In other words, the strategy of ignoring questions posed by the antagonists with discourse integrated politeness, seemed to be working for the Speaker. This allowed the critical discussion to proceed to the next stage even if the rules of procedure were being flawed and a fallacy was being committed (Tindale.2006).

Further into the discussion, Hon. Nandala-Mafabi, a vocal member of the opposition, pointed out that the ruling of the $9^{\text {th }}$ Parliament which was being quoted as precedent states that "Any Member can bring a Bill at any time." The Speaker conceded that "There is no Bill. We are dealing with the Report". Clearly a 'Report' is different from a 'Bill' in parliamentary discourse; but the Speaker ruled in favour of continuing to present the Committee Report. This is another instance where the "authority of control" in parliamentary discourse superseded the actual interpretation of the procedural rules. Since the Speaker is the reinforcement agent of the Parliamentary Rules of Procedure, she could "argue" her way out of a fallacious discursive manouevre. Here we see her using her knowledge of the regulative terminologies to undermine the antagonist submission which could have created critical doubt against the protagonist's standpoint (Gabor.2014).

Apart from the manipulation of the topics, the material therein and the calculated, integrated manoeuvering of the regulative rules, the context of the debate was still threatening and non-conducive for an effective and orderly critical discussion. At around 1.00pm of the same $27^{\text {th }}$ September 2017, Hon. Lucy Akello pointed out:

"I was called at $9.00 \mathrm{am}$ by our cleaner and she told me that the chapel had been occupied by soldiers I did not believe her so I went there before coming into the House. I discovered that both the Anglican and Catholic chapels have been occupied by soldiers...

Yes there are soldiers there and they are not allowing anyone to access that place. As our country our motto says "For God and my country". Why are we pretending? Why are soldiers invading our places of worship?". ."(Hansards, 19/12/2017)

This intervention is important to our analysis not so much for its form, but rather for its setting the tone of threat and intimidation for the discussion and indeed at $12.10 \mathrm{pm}$ the Speaker announced: "Order! Okay Honourable Members, I will suspend the House until $2.00 \mathrm{pm}$ to establish what is happening in the place of worship. The House is suspended." In this instance, one notes that apart from the manipulation of what is being debated even the atmosphere under which it is being done projects the reality of a derailed strategic maneuvering. In this case, the presence of soldiers finally caused the parliamentary debate to be suspended.

Indeed, the Debate that continued in the afternoon of $27^{\text {th }}$ September 2017 pretty much evolved around the "people in the Catholic and Anglican Chapel"; with the Minister of Internal Affairs Hon. Jeje Odong claiming that "there were cups and plates but the utensils were in the corridor, not in the Chapel..." and Hon. Tinkasiimire claiming that he found "soldiers inside the Chapel but they were praying." The Speaker at one moment declared: "Honourable Members, you are about to breach the Rules of conduct of this House." The Leader of the Opposition Hon. Winfred Kiiza pleaded: Madam Speaker, we cannot continue with the debate as if it is business as usual when we see places of worship being attacked in a place where laws are made. I plead with you Madam Speaker that ....you adjourn Parliament and iron out these issues." The strategy of emotional outrage did not stay the debate in order to deal with the threat of the soldiers. In the end, the Speaker ruled that: "Honourable Members, I have already instructed the Clerk [of Parliament] to give us a report on all the things which were tabled here. Let us go to the next item." Although 73 MPs afterwards continued and contributed to the debate up to $8.59 \mathrm{pm}$, the presence soldiers who were apparently from the Special Forces Command and not part of the security staff of the Sergeant- at-arms constituted a threat to the resolution process and according to Gabor (2014); this can be considered as a fallacious manoeuvre and thus a cause of derailment to the strategic maneuvering. Based on the persistence of this threat one can surmise that the regulative framework of parliamentary debate was not fully realized during the first session of the presidential age limit debate.

\subsection{The Second Session of the Debate on Presidential Age Limit}

Whereas the first session of the Presidential Age limit debate was mainly focusing on the confrontational stage where the differences of opinion are brought to light and topics are selected, the second took the arguments to the middle stage of opening up the arguments and bringing to bear the empirical evidence to achieve credibility and finally persuade arguers to vote for either side of the debate.

Hon. Kahunde, NRM Woman Rep. Kiryandongo, who was the first to speak stated that:

"I held 50 consultative meetings throughout the District and I beg to report to the house that in all those meetings held in different parishes, the proposal on the amendment Article 102 (b) was greatly opposed. In addition, $90 \%$ of the people who turned up for the meetings instructed me "not to touch" Article 
102(b)"( Hansards, 20/12/2017)

First I need to explain the figures of speech that had evolved from the discourse surrounding the presidential age limit debate. For the antagonists mainly opposing the Bill, their slogan was: "Don't touch it" [the Constitution/the Magyezi Bill] in Luganda, the language of Central Uganda, it was translated as "Togikwatakko". In Runyankore, the Western Uganda language where the ruling National Resistance Movement (NRM) party has its stronghold, the slogan was "Gikwateho" [Touch it]. This now explains the figurative summary of Hon. Kahunde who was appealing to fellow MPs and the audience to oppose the amendment. She was using the ritualized language for persuasion.

Hon. Norah Bigirwa, NRM Woman Rep. Buliisa, reported:

"I am here to relay the position of the people that I represent. The majority of the people in four consultative meetings allowed us to amend these Articles. But in the eight meetings we were told not to amend(Applause) ."(Hansard, 20/12/2017)

This was an objective empiricalisation of the debate. Although she is from the ruling party, she conveyed the will of the majority of her people who were opposing the Bill. She carried through the reasonableness of her argument right up to the conclusion of her submission as is expected of a people's representative in parliamentary discourse. (Eemeren. 2017).

Hon Charles Ngabirano, NRM , Rwampara County reported that his people supported the amendment and he finished with a face-threatening act:

Therefore I would like to urge my colleagues that we should amend the Constitution and Concentrate on development. It is a shame that as a country with good climate that we are not productive. We are languishing in poverty; we do not have enough food"."(Hansards, 20/12/2017)

Blaming the famine and non-productivity on the people was ment to make them reject wasting time on any more debates. According to this arguer, it's as if the House's voting in favour of the Bill was long overdue.

Hon Patrick Nsamba, NRM, Mubende was passionate in his appeal:

I call upon you not to succumb to fear.....This decision is not about how you fear the regime, it is about how much you love this country... Religious and cultural leaders like the Kabaka of Buganda have spoken against this amendment. Senior citizens have aired their views, we must listen to these voices..."."( Hansards, 20/12/2017)

This is a culture contextualized argument. In other words, if the King of the five million Baganda has already indicated 'No support' and the wise elders have also endorsed the "No", then what more convincing voices do you need to hear in order to say "No" as well? Listen to the voices of reason and wisdom and say "No" to the Bill. It is a typical rhetorical manoeuvre where the trusting listener gets entangled into the socio-cultural constraints that have been span around him/her through the persuasive argument (Ionescu-Ruxandoiu et al.2012) The arguer is counting on the institutionalized relationship between the Kabaka and his loyal subjects to sway the argument towards his side.

Hon. Joy Atim OngomUganda People's Congress (UPC), Woman Rep. Lira, made her statement:

In Lira Municipality alone I had more than 6,000 people in one gathering but it was very unfortunate that we were dispersed with tear gas and that was the circumstance where you heard that Hon. Cecilia Ogwal was beaten. The voters gave me their information and the people said "No" to the Amendment of Article 102(b)"."( Hansards, 20/12/2017)

The arguer presented her empirical evidence and painted the image of the circumstances as she consulted her constituency. Hers was an appeal to oppose the Bill using circumstantial evidence. Her closing call was emphatic with the bitter recall of beatings and tear gas. Implicitly those are interruptions that are fallacious in nature and derail strategic maneuvering.

Hon. Francis Mwijukye, Forum for Democratic Change (FDC), Buhweju County, used a very compelling metaphor:

Madam Speaker if the presidency was a vehicle, it had been given two limits: the front one and the rear one. In (2) and (5) the front brakes were removed because the driver was good, the car was in goo mechanical condition and the road was also good.

This time round, we are saying the vehicle is still in good condition, the driver can still drive and the road is 
still good, we should also remove the rear brakes. This is dangerous because we shall have a driver that is driving without brakes." (Hansards 20/12/2017).

In short, the MP was arguing using reasonableness at its finest moment. Technically, he is staging a face-threatening act to whoever dares hand over the country to a driver with no brakes at all. He is inviting the audience to critical thinking and at the same time sending a danger signal to those who would dare say "Yes" to the Amendment.

Another one that I find discursively interesting is Hon.Okello Oryem's submission (Minister of State for Foreign Affairs):

"I come from Chua East County and we made it clear that we amend the Constitution; ....The people of my constituency are satisfied with the situation- they have a tarmac rod that was never there since independence. They have electricity at single sub-county in Kitgum district, there is peace and security...Every year30-40 students go abroad to study on scholarships of different forms." ( Hansards, 20/12/2017).

For this MP, the particular contents of the Bill do not matter; the presidential age limit Bill for him and for many NRM supporters represents the specific benefits his sub-county has got from the current government's being in power. This is no surprise to us since, as a Minister in the current NRM Government, his conduct and parliamentary discourse are shaped and constrained by his institutional orientation and institutional relationship to government: his goal is to praise government.

Lastly, I selected Hon. Denis Oguzu, Maracha County, who is an 'independent' in terms of political leaning, because he made a moving and persuasive rhetorical submission:

"The people I represent think this is a Bill, which will go down in our history as the most immoral, irrational, one bent on entrenching a clan rule in this country. So far, too long Ugandans have been used as a ladder for other people to climb to their own destiny and the people of Maracha have come to realize this ....We are saying No"(Hansards, 20/12/2017)

Interestingly, like the preceding orator, this is also an MP from Northern Uganda but this time from the North Western part, West Nile, the home of the former president Idi Amin Dada who had declared himself Life President. Based on the past negative experience which the arguer later refers to, he opts for opposing the motion. The MP makes his institutional identity relevant to the communicative activity performed. His goal was to steer the audience from the devastating effects of life presidency, a constitutional danger which, according to him, still looms over the country.

As the second session on the presidential age limit debate drew towards the end, the Leader of Opposition, Hon. Winifred Kiiza pointed out that some areas had been denied consultations and two members of the house had been "arrested as they came to cast their vote". To this strong criticism the Speaker retorted: "Honourable members, we wasted the whole of Monday and Tuesday under the command of the Leader of Opposition [who] failed to prevail over her group.... Your hands are not clean.....Those members were attempting to insult parliament. Honourable Members, let us proceed with the roll call." Subsequently, the Parliament returned to its ritualized discourse, the Speaker announced that the Bill has been read for the third time. 317 members voted "Yes" against 97 "No" and the amendment bill was carried according to the official records of Parliament. In other words, it did not matter for the Speaker of the Parliament of Uganda, the person enforcing the regulative rules that the atmosphere in the chambers was not conducieve for effective debate or that some legislators were impended from participating in the final stage of resolving the differences. With her characteristic integrated politeness she swept away the security forces violation of the sanctity of parliament and submissions that were critical to the process of resolving the difference of opinions. Under such conditions, the final proceeding to vote and recording of the motion being carried can only be seen as a statistical gimmick and not a discursive conclusive resolution of the differences of opinion.

\section{Conclusion}

The reader can now observe that the whole two sessions of the Presidential Age Limit Debate in Uganda were conducted with the violence, fights and arrests simmering underneath the ritualized parliamentary discourse. In spite of the integrated institutionalized politeness formulae, one could feel the silent but palpable discursive tension between the Speaker of Parliament and the Leader of Opposition. The first session that was meant to present the differences of opinion ans set the stage for the critical discussion ended up with the session being adjourned due to the overhanging threat of soldiers camping in the chapels of parliament. The second session which was meant to carry the discussion to the opening up of the arguments, bringing to bear empirical evidence and lead the discussion to credibility was riddled with instances of fallacious moves that were undermining the antagonists' submissions. One can conclude therefore, that although contributions based on the concept of reasonableness, capturing the reality 
with empirical evidence were submitted as expected in parliamentary discourse (Eemeren .2017) and the debate evolved through most of the stages of the critical discussion, the final decision obtained through the votes did not show that a resolution of differences agreeable to the two parties of the debate had been reached. The carrying of the motion was recorded as part of the ritualized discourse but both parties remained violently fist-pitted against one another. The parliamentary debate on the presidential age limit Bill in this case did not offer an effective channel for discursively dealing with the differences of opinion. In the case under study, the conditions did not allow the pragma-dialectic theory to work well. Finding an alternative medium for mediation between the politically estranged protagonists and antagonists would require discursively, read democratically, dealing with the fallacies that explicitly or implicitly derailed the manouvering strategies.

\section{References}

Eemeren, F. H. van. (2017). Argumentation Theory and Argumentative Practices: A Vital but Complex Relationship. Informal Logic, 37(4), 322-350. https://doi.org/10.1023/b:arti.0000046007.11806.9a

Eemeren, F. H. van, \& Garssen, B. (2013). Argumentative Patterns in Discourse. OSSA Conference Archives, 42. Retrieved from https://scholarwindsor.ca/ossaarchive/OSSA10/paperand commentaries/42;

Eemeren, F. van., Garssen, B., \& Craig, R. T. (2011). Exploiting the room for strategic maneuvering in argumentative discourse: Dealing with audience demand in the European Parliament OSSA Conference Archive, OSSA 9 University of Windsor, Scholarship at UWindsor.

Eemeren, F. H. van, \& Houtlosser, P. (2000b). Rhetorical analysis within a pragma-dialectical framework: The case of R. J. Reynolds. Argumentation, 14, 293-305.

Goffman, E. (1981). Forms of Talk. Oxford: Blackwell.

Ilie, C. (2006). Parliamentary Discourses, In keith Brown (Ed.) Encyclopedia of Languages and Linguistics. $2^{\text {nd }}$ Edition, Vol. 9, pp188-197.Oxford: Elsevier.

Hansards December 2017: In the Parliament of Uganda, Official Report of the Proceedings of Parliament, Second Session $-20^{\text {th }}$ Sitting -Second Meeting, published Wednesday, $20^{\text {th }}$ December 2017.

Hansards December 2017: In the Parliament of Uganda, Official Report of the Proceedings of Parliament, Second Session $-21^{\text {st }}$ Sitting -Second Meeting, published Tuesday, $19^{\text {th }}$ December 2017.

Ionescu-Ruxandoiu, Roibu, M., \& Constatinescu, M. V. (2012). (Eds.) Parliamentary Discourse across cultures: Interdisciplinary Approaches. Cambridge Scholars Publishing. New Castle-upon-Tyre, UK.

Jaworski, A., \& Coupland, N. (1999). The Discourse Reader, Landon and New York, Routledge.

Mukasa E. Ssemakula. The19666 Crisis, The Buganda home Page, http://www.buganda.com/honor.htm, 3/20/2019

Mwiinga, C. (2015). A Critical Discourse Analysis of the Parliament Debate on the lifting of the Immunity of the Fourth Republican President of Zambia in 2013. Dissertation. University of Zambia. Lusaka.

Tindale, C. W. (2006). Constrained Maneuvering: Rhetoric as a Rational Enterprise, In Argumentation, Vol. 20 No.4, pp. 477-466. Kluwer Academic Publishers. https://doi.org/10.1007/5/0503-007-9026-2

The East African, Wednesday, October 18, 2017

The New Vision, Saturday, September $9^{\text {th }}, 2017$.

The Observer, Saturday, October $6^{\text {th }}, 2017$.

The Observer, Monday, September 19 ${ }^{\text {th }}, 2017$.

The Telegraph,Thursday, September 28 2017.

Zenker, F. (2009). Review of Eemeren, F.H. van, Garssen, B, and Meuffels, B. Fallacies and Judgments of Reasonableness. Amsterdam: Springer. 